\title{
EFFECT OF GEOPHYSICAL PARAMETERS ON ATTENUATION OF CONTAMINANT IN FRESHWATER COASTAL AQUIFERS
}

\author{
ADEGOKE JAMES ADEYEMO ${ }^{1}$, OLATUNDE I. POPOOLA ${ }^{1}$, \\ OLUDOTUN OMONIYI FALUYI ${ }^{* 1,2}$ \\ ${ }^{1}$ Department of Physics, University of Ibadan, Ibadan Nigeria \\ ${ }^{2}$ Department of Physics and Materials Science, Kwara State University, \\ Malete Kwara State Nigeria
}

\begin{abstract}
Freshwater coastal aquifers can be contaminated by influx of seawater. The study investigated the effect of geophysical parameter such as seepage velocity $(v)$ determined empirically on the mass flux $(J)$ of contaminant through the coastal aquifers. Porosities of the grains were determined and tagged samples A to E. $v$ was obtained in the experimental setup. Results showed that hydraulic gradient ranged between 3.233 to 0.317 while the corresponding values of contaminant $J$ ranged between 0.302 to $5.381 \mathrm{Kgm}^{-2} \mathrm{~s}^{-1}$ within 60 to 360 seconds. Therefore, the attenuation coefficients of $J$ decreased with increased in flow rate of fluid through the samples.
\end{abstract}

Keywords: seepage velocity, porosities, hydraulic gradient, freshwater and coastal aquifers

\section{INTRODUCTION}

Population growth and agricultural development in coastal areas have increased the demand for freshwater. As a result of this demand more stress is being placed on coastal aquifers. Saltwater intrusion is the most common contamination problem in coastal aquifers and a major constraint imposed on groundwater utilization [1]. Saline contamination of freshwater resources can cause significant social, economic and environmental hazards. When pumping takes place in excess of replenishment, the drawdown of the water table creates a piezometric head, the fresh water becomes less than the adjacent salt water wedge. Then the saline water moves inland causing a saltwater intrusion. The saltwater may reach the well which becomes contaminated. Saltwater intrusions have occurred in many coastal aquifers.

A natural fringe or separation exists between discharging fresh groundwater and seawater in coastal aquifers. This is referred to as the saline interface in this study, but it is also known as the sea/saltwater-freshwater interface. The position of the saline interface is dynamic and depends on the geological formation, hydraulic gradient, topography, and the quantity of freshwater moving through the aquifer system [2]. The saline interface is influenced by a number of processes forming a complex and variable system. The density contrast between fresh groundwater and saline water leads to mixing and convective circulation at the saline interface. The interface is thus characterized by a zone of diffusion as the saline water mixes with the discharging freshwater.

Under normal conditions freshwater flows from inland aquifers and recharge areas to coastal discharge areas to the sea. In general, groundwater flows from areas with higher groundwater levels (hydraulic head) to areas with lower groundwater levels. This natural movement of freshwater towards the sea prevents saltwater from entering freshwater coastal aquifers [3].

\footnotetext{
* Corresponding author, email: oludotunfaluyi@ gmail.com

(C) 2019 Alma Mater Publishing House
} 
Finally, saltwater and freshwater do not form an inert interface. There is diffusive mixing of salt ions across the interface, which diminishes the interface and accelerates saltwater intrusion. The extent of mixing is a function of both freshwater flow rates and geologic characteristics of the aquifer. Consequently, the most accurate models of saltwater intrusion incorporate diffusion components based on sediment composition and flow patterns [4].

In coastal aquifers under natural conditions, the lighter freshwater lies over the heavier saline water and the flow is usually from the aquifer to the sea and the discharge zone to the sea is immediately above interface of saltwater and freshwater. Mixing of freshwater and saltwater occurs only by molecular diffusion while mechanical dispersion and advection are negligible because the aquifer is homogeneous which results in steady state flow of seepage velocity [5,6]. As a result, the mixing zone between saltwater and freshwater is small compared to the thickness of the aquifer, and an abrupt, well-defined interface is usually assumed. At a point on the interface between the freshwater and saline water, the pressure of the freshwater, $\rho_{f} g h_{f}$, usually exceeds the pressure of the saline water, $\rho_{s} g h_{s}$, causing the flow from land to sea. The fresh and saline groundwater have densities $\rho_{f}$ and $\rho_{S}$. But when pumping takes place in excess of replenishment, the drawdown of the water table creates a piezometric head in the freshwater that becomes less than in the adjacent saltwater wedge. Then the saline water moves inland causing a saltwater intrusion.

\section{THEORETICAL BACKGROUND}

Analyses of saltwater intrusion assumed that mixing occurs at the transition zone between seawater and freshwater and hydrodynamic dispersion requires the solution of two partial differential equations representing the mass conservation principle for the variable-density fluid (flow equation) and for the dissolved solute (transport equation). Darcy's law governs the flow equation of groundwater and Fick's laws govern transport equation of dissolved contaminant. The properties of the coastal aquifers such as hydraulic conductivity, effective diffusion coefficient and porosity contribute to the ability of the aquifer to reduce the severity of groundwater contamination which is known as soil attenuation or soil filtration.

The mass flux of saltwater intrusion in coastal aquifer can be modeled by applying some constrains on Darcy's law and Fick's laws.

According to Darcy's law, the volumetric flow rate per unit area (volume flux) is directly proportional to the hydraulic gradient that is:

$$
q=-K \frac{d h}{d l}
$$

and Seepage velocity,

$$
V=\frac{q}{\emptyset}
$$

where $\mathrm{K}$ is the hydraulic conductivity and $d h / d l$ is the hydraulic gradient (i).

According to first Fick's law of diffusion, the amount of mass of saltwater passing through a unit area per unit time is called mass flux in $\mathrm{kgm}^{-2} \mathrm{~s}^{-1}$.

The mass flux is directly proportional to the gradient of concentration [7] that is:

$$
J=-D_{o} \frac{d C}{d x}
$$

Where $J$ is the mass flux of substance $\left(\mathrm{Kg} / \mathrm{m}^{2} \mathrm{~s}\right), D_{o}$ is the effective diffusion coefficient of soil and $d c / d x$ is gradient of concentration.

According to one dimensional second Fick's law of diffusion, the rate of change of concentration with time is directly proportional to the second order of concentration gradient that is: 


$$
\frac{d C}{d t}=D_{o} \frac{d^{2} C}{d x^{2}}
$$

Where $C$ is the concentration of saltwater in porous medium, $t$ is the time of diffusion and $x$ is the distance (length) of diffusion.

The concentration of contaminant can be expressed by exponential function of time [8, 9].

$$
C=C_{o} \exp \left(-\lambda_{t} t\right)
$$

Also, it can be expressed by exponential function of distance [9-11].

$$
C=C_{o} \exp \left(-\lambda_{x} x\right)
$$

Where $C_{o}$ is the concentration at the interface between freshwater and freshwater when $t=0$ and $x=0$ with magnitude $1025 \mathrm{kgm}^{-3}$.

Differentiating equations (5) and (6) with respect to $t$ and $x$ respectively:

$$
\begin{aligned}
& \frac{d C}{d t}=-\lambda_{t} C_{o} \exp \left(-\lambda_{t} t\right) \\
& \frac{d C}{d x}=-\lambda_{x} C_{o} \exp \left(-\lambda_{x} x\right) \\
& \frac{d^{2} C}{d x^{2}}=-\lambda^{2}{ }_{x} C_{o} \exp \left(-\lambda_{x} x\right)
\end{aligned}
$$

where $\lambda_{t}$ is the coefficient of attenuation and $\lambda_{x}$ is the coefficient of filtration.

Substituting equations (7) and (9) into equation (4):

$$
-\lambda_{t} C_{o} \exp \left(-\lambda_{t} t\right)=D_{o} \lambda_{x}^{2} C_{o} \exp \left(-\lambda_{x} x\right)
$$

from equations (5) and (6):

$$
\begin{aligned}
\operatorname{In}\left(C / C_{o}\right)=-\lambda_{t} t \quad \operatorname{In}\left(C / C_{o}\right) & =-\lambda_{x} x \quad-\lambda_{t} t=-\lambda_{x} x \quad \lambda_{t}=\lambda_{x}\left(\frac{x}{t}\right) \\
\lambda_{t} & =\lambda_{x} V
\end{aligned}
$$

Therefore, equation (10) can be written as:

$$
\begin{gathered}
-\lambda_{x} V C_{o} \exp \left(-\lambda_{x} x\right)=D_{o} \lambda_{x}^{2} C_{o} \exp \left(-\lambda_{x} x\right) \\
-V C_{o} \exp \left(-\lambda_{x} x\right)=D_{o} \lambda_{x} C_{o} \exp \left(-\lambda_{x} x\right) \\
\lambda_{x}=-\frac{V}{D_{o}}
\end{gathered}
$$

Substituting equation (14) into equation (8):

$$
\frac{d C}{d x}=-\frac{V}{D_{0}} C_{o} \exp \left(-\frac{W}{D_{0}}\right) x
$$

Insert equation 15 into equation 3 the mass flux is derived and expressed as:

$$
J=V C_{o} \exp \left(\left(-\frac{V}{D_{o}}\right) x\right)
$$




$$
\operatorname{In}(J)=\operatorname{In}\left(V C_{o}\right)-\left(\frac{V}{D_{o}}\right) x
$$

where $V C_{o}=J_{o}$ is the initial mass flux when diffused length $x=0$ at time $\mathrm{t}=0$ and $J$ is final mass flux when diffused length $x \neq 0$ and time $\mathrm{t} \neq 0$.

Our derived mathematical model developed in equation (16) was used to simulate saltwater movement in sand media of different hydraulic conductivities with various hydraulic gradients at different flow length $X$ from the interface of saltwater and freshwater. Parameters used in simulation are shown on Table (6) which was obtained empirically.

\section{MATERIALS AND METHOD}

Soil sample was collected in a stream at Tanke, Ilorin Kwara State close to University of Ilorin. The sample was washed to remove the micro organism that can cause decomposition and it was sun dried. The pebbles were picked from the sample and packed in a polythene bag in which it was taken to the laboratory. The sample was sieved into five different grain sizes of 125, 250,350, 400 and $450 \mu \mathrm{m}$ and the grain sizes were tagged samples A, B, C, $\mathrm{D}$ and $\mathrm{E}$ respectively. The porosity $(\varnothing)$ of the samples A, B, C, D and E were determined using volumetric method. It must be noted that the porosity of a natural sand deposit depends on the shape of the grains, the uniformity of the grain size, and the conditions of sedimentation.

\subsection{Experimental procedure}

The experimental setup consisted of two arms of calibrated cylinder glass with diameter $1.2 \times 10^{-2} \mathrm{~m}$ erected vertically and joined together with a similar glass cylinder in the horizontal position which housed the samples. Saturated sample A of length $x$ with air completely eliminated was inserted into the horizontal glass and screen at both end before commencement of the experiment. Freshwater was filled in the arm labeled $\mathrm{M}$ to $27 \mathrm{~cm}$ mark and saltwater which was colored with red dye (neutral pigment) was filled in the arm labeled $\mathrm{N}$ to $15 \mathrm{~cm}$ mark. The controls were opened at the same time to allow flow to occur. Therefore, the volume of freshwater displaced volume of saltwater in the setup. The hydraulic gradient between freshwater and saltwater was obtained by determining the difference between hydraulic heads of freshwater and saltwater and then divides by the flow length $X$ between the two heads. The volumetric flow rate was computed from volume of fluid displaced between the two arms per time taken and it was denoted as $\mathrm{Q}$ with unit of $\mathrm{m}^{3} \mathrm{~s}^{-1}$. Darcy flux (volume flux) was obtained by dividing the volumetric flow rate with cross sectional area of the tube and it was denoted as $v_{x}$ with unit of $\mathrm{ms}^{-1}, v_{x}=\mathrm{Q} / \mathrm{A}$ (Figure 1).

Where A is cross sectional area of the cylindrical glass which is $\frac{\pi D^{2}}{4}$ and $d$ is the diameter of the cylindrical glass, given as $1.2 \times 10^{-2} \mathrm{~m}$ ). The flow length $X$ was determined from the distance of the movement of the red dye from the interface of freshwater and saltwater. The seepage velocity $(V)$ which is the average velocity of water flow through the pores was determined by dividing the volume flux $\left(v_{x}\right)$ by porosity $(\varnothing)$. The effective diffusion coefficient $\left(D_{o}\right)$ of soil was determined from of the slope of plot of square of flow length $X\left(X^{2}\right)$ against time $(\mathrm{t})$ in second. The effective diffusion coefficient $\left(D_{o}\right)$ of the sample incorporated grain size, uniformity of the grain and path length of flow. The procedure was repeated for samples B, C, D and E. The hydraulic gradient $i$, volumetric flow rate $\mathrm{Q}$, volume flux $v_{x}$, seepage velocity $V$, effective diffusion coefficient $D_{o}$ and flow length $X$ for each sample were determined. 


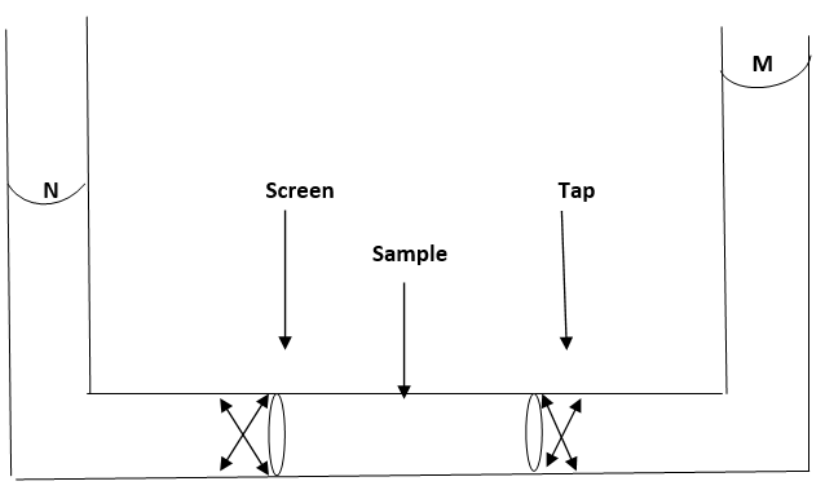

Fig. 1. Experimental setup to determine volume flux, hydraulic gradient and diffusion coefficient.

\section{RESULTS AND DISCUSSION}

Results of hydraulic gradients, flow lengths $\mathrm{x}$, volume flux and seepage velocity between freshwater and saltwater for samples A, B, C, D and E respectively were determined and presented in Tables 1-5. It was observed that the volume flux increased with porosity while hydraulic gradients decreased with porosity. The results from the experimental procedure showed that hydraulic gradient for samples A, B, C, D and E are 3.233, 1.049, 0.468, 0.364 and 0.317 while the corresponding values of contaminant volume flux are $0.295 \times 10^{-4}, 2.063 \times 10^{-4}, 3.855$ $\times 10^{-4}, 4.554 \times 10^{-4}$ and $5.250 \times 10^{-4} \mathrm{~ms}^{-1}$, respectively within time intervals of 60 to 360 seconds in Tables $1-5$. Hence, it showed that energy known as hydraulic gradient required in overcoming hydraulic resistance is high when porosity is low whereby the contaminant volume flux is reduced vice versa.

The values porosity, hydraulic conductivity and effective diffusion coefficient of the homogeneous samples A, B, C, D and E were presented in Table 6. Hydraulic conductivities of the samples were obtained the slopes the graphs of volume flux against hydraulic gradient as shown in Figure 2. The graphs of volume flux against hydraulic gradient for samples B, C, D and E follow the same pattern in Figure 2 The effective diffusion coefficients of saltwater contaminant through samples A, B, C, D and E were obtained from the slopes of plots between the square of flow length $x$ and time of flow as show in Figure 3. The graph of the square of flow length against time for samples B, C, D and E follow the same pattern in Figure 3.

The mass flux was simulated numerically from the developed model $J=V C_{o} \exp \left(-\frac{V}{D} X\right)$ in this study using data in Table 6 with hydraulic gradients ranged from 0.6 to 4.2 and flow length $X$ ranged from $0 \leq X \leq 14 \mathrm{~cm}$. Natural logarithm of mass flux was determined from the values of mass flux of saltwater contaminant through samples A, B, C, D and E. The average values of natural log of mass flux $\mathrm{J}$ simulated when average hydraulic gradient is 2.1 were obtained as presented in Table 7 .

The plot of natural logarithm of mass flux (In J) against flow length $x$ gives a straight line graph and the negative slope is the attenuation coefficient of the samples as shown in Figure 4 for sample A. The plots of natural logarithm of mass flux against flow length $x$ for other samples follow the same pattern.

Table 8 showed the Values of attenuation coefficient $\lambda$ for samples A, B, C, D and E by simulation. The concentration of saltwater attenuated at the different positions within the flow length of range $0 \leq X \leq 14 \mathrm{~cm}$ for samples $\mathrm{A}, \mathrm{B}, \mathrm{C}, \mathrm{D}$ and $\mathrm{E}$ for the simulation were obtained by substituting the attenuation coefficient $\lambda$ into equation 6. The values of concentration of saltwater attenuated at the different positions within the flow length of range $0 \leq X \leq 14 \mathrm{~cm}$ for samples $\mathrm{A}, \mathrm{B}, \mathrm{C}, \mathrm{D}$ and $\mathrm{E}$ for simulation are shown in Table 9 . The difference in concentration within the flow length $0 \leq X \leq 14 \mathrm{~cm}$ for samples A to E were 312.70, 894.50, 993.60, 1008.40 and $1017.90 \mathrm{Kgm}^{-3}$ and it was obtained from Table 9.

The concentration gradient of diffusion which is the difference in concentration of saltwater per flow length $x$ was calculated with the magnitudes of 2.402, 4.4896, 7.137, 7.227 and 7.266 $\mathrm{Kgm}^{-4}$ for samples A, B, C, D and E, respectively. The driving force of contaminant in a porous medium is the concentration gradient of diffusion and it increased with increase in porosity in the simulation. This implied that the diffusion of saltwater contaminant 
through coastal aquifers can be reduced by selecting material with low porosity which will dampen the seepage velocity.

Table 1. Experimentally determined values of hydraulic gradient i, specific discharge q, seepage velocity and flow length $\mathrm{x}$ for sample $\mathrm{A}(\emptyset=0.25)$.

\begin{tabular}{|c|c|c|c|c|c|c|c|c|}
\hline $\begin{array}{l}\text { Time } \\
\text { (Sec.) }\end{array}$ & $\begin{array}{l}\text { Hydraulic head } \\
\text { of saltwater } \\
(\mathrm{cm})\end{array}$ & $\begin{array}{l}\text { Hydraulic } \\
\text { Head of } \\
\text { freshwater } \\
\quad(\mathrm{cm})\end{array}$ & $\begin{array}{l}\text { Hydraulic } \\
\text { gradient i }\end{array}$ & $\begin{array}{c}\text { Flow } \\
\text { length } \\
\mathrm{X}(\mathrm{m}) \\
\times 10^{-2}\end{array}$ & $\begin{array}{l}\mathrm{X}^{2}\left(\mathrm{~m}^{2}\right) \\
\times 10^{-3}\end{array}$ & $\begin{array}{l}\text { Volumetric flow } \\
\text { Rate, } \mathrm{Q}\left(\mathrm{m}^{3-1} \mathrm{~s}^{-1}\right) \\
\times 10^{-8}\end{array}$ & $\begin{array}{l}\text { Volume flux, } \\
\mathrm{q}^{-1}\left(\mathrm{~ms}^{-4}\right) \times 10^{-4}\end{array}$ & $\begin{array}{c}\text { Seepage } \\
\text { Velocity } \mathrm{q} / \varnothing \\
\left(\mathrm{ms}^{-1}\right) \times 10^{-4}\end{array}$ \\
\hline 60 & 16.10 & 25.90 & 3.960 & 2.475 & 0.613 & 4.148 & 2.063 & 8.252 \\
\hline 120 & 16.60 & 25.40 & 2.444 & 3.600 & 1.300 & 4.022 & 2.000 & 8.000 \\
\hline 180 & 17.10 & 24.90 & 1.651 & 4.725 & 2.233 & 3.959 & 1.969 & 7.875 \\
\hline 240 & 17.60 & 24.40 & 1.162 & 5.850 & 3.422 & 3.922 & 1.950 & 7.800 \\
\hline 300 & 18.00 & 24.00 & 0.889 & 6.750 & 4.556 & 3.771 & 1.875 & 7.500 \\
\hline 360 & 18.30 & 23.70 & 0.727 & 7.425 & 5.513 & 3.555 & 1.768 & 7.072 \\
\hline
\end{tabular}

Table 2. Experimentally determined values of hydraulic gradient $\mathrm{i}$, specific discharge q, eepage velocity and flow length $\mathrm{x}$ for sample $\mathrm{B}(\varnothing=0.300)$.

\begin{tabular}{|c|c|c|c|c|c|c|c|c|}
\hline $\begin{array}{l}\text { Time } \\
\text { (Sec.) }\end{array}$ & $\begin{array}{l}\text { Hydraulic head } \\
\text { of saltwater } \\
(\mathrm{cm})\end{array}$ & $\begin{array}{l}\text { Hydraulic } \\
\text { Head } \\
\text { of } \\
\text { freshwater } \\
(\mathrm{cm}) \\
\end{array}$ & $\begin{array}{l}\text { Hydraulic } \\
\text { gradient i }\end{array}$ & $\begin{array}{l}\text { Flow } \\
\text { length } \\
\mathrm{X}(\mathrm{m}) \\
\times 10^{-2}\end{array}$ & $\begin{array}{l}X^{2}\left(\mathrm{~m}^{2}\right) \\
\times 10^{-3}\end{array}$ & $\begin{array}{l}\text { Volumetric flow } \\
\text { Rate, } \mathrm{Q}\left(\mathrm{m} \mathrm{s}^{3-1}\right) \\
\times 10^{-8}\end{array}$ & $\begin{array}{l}\text { Volume flux, } \\
\left.\mathrm{q}^{-1} \mathrm{~ms}^{-4}\right) \\
\times 10^{-4}\end{array}$ & $\begin{array}{l}\text { Seepage } \\
\text { Velocity } \\
\text { q/Ø } \\
\left(\mathrm{ms}^{-1}\right) \times 10^{-4}\end{array}$ \\
\hline 60 & 17.30 & 24.70 & 1.430 & 5.175 & 2.916 & 8.672 & 4.313 & 14.325 \\
\hline 120 & 18.10 & 23.90 & 0.832 & 6.975 & 4.865 & 7.793 & 3.875 & 12.917 \\
\hline 180 & 18.55 & 23.45 & 0.614 & 7.988 & 6.380 & 6.693 & 3.328 & 11.094 \\
\hline 240 & 18.85 & 23.15 & 0.496 & 8.663 & 7.504 & 5.807 & 2.888 & 9.625 \\
\hline 300 & 19.05 & 22.95 & 0.428 & 9.113 & 8.304 & 5.090 & 2.531 & 8.438 \\
\hline 360 & 19.20 & 22.80 & 0.381 & 9.450 & 8.930 & 4.525 & 2.250 & 7.500 \\
\hline
\end{tabular}

Table 3. Experimentally determined values of hydraulic gradient $\mathrm{i}$, specific discharge q, seepage velocity, mass flux $\mathrm{J}$ and flow length $\mathrm{x}$ for sample $\mathrm{C}(\varnothing=0.330)$.

\begin{tabular}{|c|c|c|c|c|c|c|c|c|}
\hline $\begin{array}{l}\text { Time } \\
\text { (Sec.) }\end{array}$ & $\begin{array}{l}\text { Hydraulic head } \\
\text { of saltwater } \\
(\mathrm{cm})\end{array}$ & $\begin{array}{l}\text { Hydraulic } \\
\text { Head } \\
\text { of } \\
\text { freshwater } \\
(\mathrm{cm})\end{array}$ & $\begin{array}{l}\text { Hydraulic } \\
\text { gradient i }\end{array}$ & $\begin{array}{l}\text { Flow } \\
\text { length } \\
\mathrm{X}(\mathrm{m}) \\
\times 10^{-2}\end{array}$ & $\begin{array}{l}X^{2}\left(\mathrm{~m}^{2}\right) \\
\times 10^{-3}\end{array}$ & $\begin{array}{l}\text { Volumetric flow } \\
\text { Rate, } \mathrm{Q}\left(\mathrm{m} \mathrm{s}^{-1}\right) \\
\times 10^{-8}\end{array}$ & $\begin{array}{l}\text { Volume flux, } \\
\mathrm{q}\left(\mathrm{ms}^{-1}\right) \\
\times 10^{-4}\end{array}$ & $\begin{array}{l}\text { Seepage } \\
\text { Velocity, } \\
\mathrm{q} / \varnothing \\
\left(\mathrm{ms}^{-1}\right) \times 10^{-4}\end{array}$ \\
\hline 60 & 18.50 & 23.50 & 0.635 & 7.875 & 6.202 & 13.192 & 6.560 & 19.879 \\
\hline 120 & 19.10 & 22.90 & 0.412 & 9.225 & 8.510 & 10.316 & 5.130 & 15.546 \\
\hline 180 & 19.50 & 22.50 & 0.296 & 10.125 & 10.252 & 8.484 & 4.219 & 12.784 \\
\hline 240 & 19.80 & 22.20 & 0.222 & 10.800 & 11.664 & 7.240 & 3.600 & 10.909 \\
\hline 300 & 19.95 & 22.05 & 0.190 & 11.138 & 12.404 & 6.222 & 3.094 & 9.375 \\
\hline 360 & 20.05 & 21.95 & 0.167 & 11.363 & 12.911 & 5.441 & 2.705 & 8.198 \\
\hline
\end{tabular}

Table 4. Experimentally determined values of hydraulic gradient $\mathrm{i}$, specific discharge q, seepage velocity, mass flux $\mathrm{J}$ and flow length $\mathrm{x}$ for sample $\mathrm{D}(\varnothing=0.375)$.

\begin{tabular}{|c|c|c|c|c|c|c|c|c|}
\hline $\begin{array}{l}\text { Time } \\
\text { (Sec.) }\end{array}$ & $\begin{array}{l}\text { Hydraulic head } \\
\text { of saltwater } \\
(\mathrm{cm})\end{array}$ & $\begin{array}{l}\text { Hydraulic } \\
\text { Head } \\
\text { of } \\
\text { freshwater } \\
(\mathrm{cm}) \\
\end{array}$ & $\begin{array}{l}\text { Hydraulic } \\
\text { gradient i }\end{array}$ & $\begin{array}{l}\text { Flow } \\
\text { length } \\
\mathrm{X}(\mathrm{m}) \\
\times 10^{-2}\end{array}$ & $\begin{array}{l}\mathrm{X}^{2}\left(\mathrm{~m}^{2}\right) \\
\times 10^{-3}\end{array}$ & $\begin{array}{l}\text { Volumetric flow } \\
3-1 \\
\text { Rate, } \mathrm{Q}\left(\mathrm{m} \mathrm{s}^{-8}\right) \\
\times 10^{-8}\end{array}$ & $\begin{array}{l}\text { Volume flux, } \\
\mathrm{q}\left(\mathrm{ms}^{-1}\right) \\
\times 10^{-4}\end{array}$ & $\begin{array}{l}\text { Seepage } \\
\text { Velocity, } \\
\mathrm{q} / \varnothing \\
\left(\mathrm{ms}^{-1}\right) \times 10^{-4}\end{array}$ \\
\hline 60 & 18.96 & 23.04 & 0.480 & 8.889 & 7.901 & 14.896 & 7.407 & 19.752 \\
\hline 120 & 19.60 & 22.40 & 0.307 & 10.126 & 10.252 & 11.317 & 5.628 & 15.008 \\
\hline 180 & 19.86 & 22.14 & 0.218 & 10.914 & 11.912 & 9.148 & 4.549 & 12.131 \\
\hline 240 & 20.11 & 21.89 & 0.161 & 11.475 & 13.168 & 7.695 & 3.827 & 10.205 \\
\hline 300 & 20.26 & 21.74 & 0.132 & 11.815 & 13.959 & 6.603 & 3.283 & 8.755 \\
\hline 360 & 20.05 & 21.95 & 0.167 & 11.363 & 12.911 & 5.441 & 2.705 & 8.198 \\
\hline
\end{tabular}

Table 5. Experimentally determined values of hydraulic gradient $\mathrm{i}$, specific discharge $\mathrm{q}$, seepage velocity, mass 
flux $\mathrm{J}$ and flow length $\mathrm{x}$ for sample $\mathrm{E}(\varnothing=0.420)$.

\begin{tabular}{|c|c|c|c|c|c|c|c|c|}
\hline $\begin{array}{l}\text { Time } \\
\text { (Sec.) }\end{array}$ & $\begin{array}{l}\text { Hydraulic head } \\
\text { of saltwater } \\
(\mathrm{cm})\end{array}$ & $\begin{array}{l}\text { Hydraulic } \\
\text { Head } \\
\text { of } \\
\text { freshwater } \\
(\mathrm{cm})\end{array}$ & $\begin{array}{l}\text { Hydraulic } \\
\text { gradient, i }\end{array}$ & $\begin{array}{l}\text { Flow } \\
\text { length } \\
\mathrm{X}(\mathrm{m}) \\
\times 10^{-2}\end{array}$ & $\begin{array}{l}X^{2}\left(\mathrm{~m}^{2}\right) \\
\times 10^{-3}\end{array}$ & $\begin{array}{l}\text { Volumetric flow } \\
\text { Rate, } \mathrm{Q}\left(\mathrm{m} \mathrm{s}^{3-1}\right) \\
\times 10^{-8}\end{array}$ & $\begin{array}{l}\text { Volume flux, } \\
\mathrm{q}\left(\mathrm{ms}^{-1}\right) \\
\times 10^{-4}\end{array}$ & $\begin{array}{l}\text { Seepage } \\
\text { Velocity, } \\
\mathrm{q} / \varnothing \\
\left(\mathrm{ms}^{-1}\right) \times 10^{-4}\end{array}$ \\
\hline 60 & 19.40 & 22.60 & 0.323 & 9.900 & 9.801 & 16.591 & 8.250 & 19.643 \\
\hline 120 & 19.90 & 22.10 & 0.200 & 11.025 & 12.155 & 12.317 & 6.125 & 14.583 \\
\hline 180 & 20.20 & 21.80 & 0.137 & 11.700 & 13.369 & 9.804 & 4.875 & 11.607 \\
\hline 240 & 20.40 & 21.60 & 0.099 & 12.150 & 14.762 & 8.145 & 4.050 & 9.643 \\
\hline 300 & 20.55 & 21.45 & 0.072 & 12.488 & 15.594 & 6.976 & 3.469 & 8.259 \\
\hline 360 & 20.60 & 21.40 & 0.063 & 12.600 & 15.876 & 6.033 & 3.000 & 7.143 \\
\hline
\end{tabular}

Table 6. Values of porosities, hydraulic conductivities, diffusion coefficients, effective diffusion coefficients and tortuosity for homogeneous samples A,B, C, D and E.

\begin{tabular}{|c|c|c|c|}
\hline Samples & Porosity & $\begin{array}{c}\text { Hydraulic } \\
\text { Conductivity } \\
(\mathrm{m} / \mathrm{s}) \times 10^{-5}\end{array}$ & $\begin{array}{c}\text { Effective Diffusion } \\
\text { Coefficient }\left(\mathrm{m}^{2} / \mathrm{s}\right) \times 10^{-5}\end{array}$ \\
\hline A & 0.250 & 0.570 & 3.310 \\
B & 0.300 & 1.870 & 3.660 \\
C & 0.330 & 7.960 & 4.080 \\
D & 0.375 & 11.700 & 4.037 \\
E & 0.420 & 17.500 & 4.680 \\
\hline
\end{tabular}

Table 7. Mean values of natural log of mass flux $\mathrm{J}$ simulated when average hydraulic gradient is 2.1 for samples $\mathrm{A}, \mathrm{B}, \mathrm{C}, \mathrm{D}$ and $\mathrm{E}$.

\begin{tabular}{|l|l|l|lc|l|}
\hline $\mathrm{X}(\mathrm{cm})$ & $\begin{array}{l}\varnothing=0.250 \\
\text { In J }\end{array}$ & $\begin{array}{l}\varnothing=0.300 \\
\text { In J }\end{array}$ & $\begin{array}{l}\varnothing=0.330 \\
\text { In J }\end{array}$ & $\begin{array}{l}\varnothing=0.375 \\
\text { In J }\end{array}$ & $\begin{array}{l}\varnothing=0.420 \\
\text { In J }\end{array}$ \\
\hline 0 & -3.240 & -2.040 & -0.690 & -0.4170 & -0.322 \\
\hline 2 & -3.300 & -2.201 & -1.220 & -1.0374 & -0.858 \\
\hline 4 & -3.360 & -2.360 & -1.740 & -1.6577 & -1.572 \\
\hline 6 & -3.410 & -2.516 & -2.269 & -2.2779 & -2.287 \\
\hline 8 & -3.470 & -2.673 & -2.800 & -3.0640 & -3.001 \\
\hline 10 & -3.530 & -2.831 & -3.322 & -3.5185 & -3.715 \\
\hline 12 & -3.580 & -2.988 & -3.850 & -4.1387 & -4.429 \\
\hline 14 & -3.640 & -3.146 & -4.374 & -4.7519 & -5.143 \\
\hline
\end{tabular}

Table 8 . Values of attenuation coefficient $\lambda$ for samples A, B, C, D and E by simulation.

\begin{tabular}{|c|c|c|}
\hline Sample & Porosity & Attenuation coefficient from model \\
\hline A & 0.250 & -2.84 \\
\hline B & 0.300 & -7.89 \\
\hline C & 0.330 & -26.30 \\
\hline D & 0.375 & -31.09 \\
\hline E & 0.420 & -34.89 \\
\hline
\end{tabular}

Table 9. Reduction in concentration of contaminants along flow length for simulation.

\begin{tabular}{|l|l|l|l|l|l|}
\hline $\begin{array}{l}\text { Flow length } \\
X(\mathrm{~m})\end{array}$ & $\begin{array}{l}\text { Concentration } \\
\left(\mathrm{Kgm}^{-3}\right) \times 10^{3} \\
\mathrm{~A}(\varnothing=0.250)\end{array}$ & $\begin{array}{l}\text { Concentration } \\
\left(\mathrm{Kgm}^{-3}\right) \times 10^{3} \\
\mathrm{~B}(\varnothing=0.330)\end{array}$ & $\begin{array}{l}\text { Concentration } \\
\left(\mathrm{Kgm}^{-3}\right) \times 10^{3} \\
\mathrm{C}(\varnothing=0.375)\end{array}$ & $\begin{array}{l}\text { Concentration } \\
\left(\mathrm{Kgm}^{-3}\right) \times 10^{3} \\
\mathrm{D}(\varnothing=0.400)\end{array}$ & $\begin{array}{l}\text { Concentration } \\
\left(\mathrm{Kgm}^{-3}\right) \times 10^{3} \\
\mathrm{E}(\varnothing=0.420)\end{array}$ \\
\hline 0.00 & 1.0250 & 1.0250 & 1.0250 & 1.0250 & 1.0250 \\
\hline 0.02 & 0.9731 & 0.7636 & 0.6231 & 0.5690 & 0.5036 \\
\hline 0.04 & 0.9238 & 0.5689 & 0.3787 & 0.3158 & 0.2475 \\
\hline 0.06 & 0.8769 & 0.4238 & 0.2302 & 0.1753 & 0.1216 \\
\hline 0.08 & 0.8325 & 0.3157 & 0.1399 & 0.0973 & 0.0597 \\
\hline 0.10 & 0.7903 & 0.2352 & 0.0851 & 0.0540 & 0.0294 \\
\hline 0.12 & 0.7503 & 0.1752 & 0.0517 & 0.0300 & 0.0144 \\
\hline 0.14 & 0.7123 & 0.1305 & 0.0314 & 0.0166 & 0.0071 \\
\hline
\end{tabular}




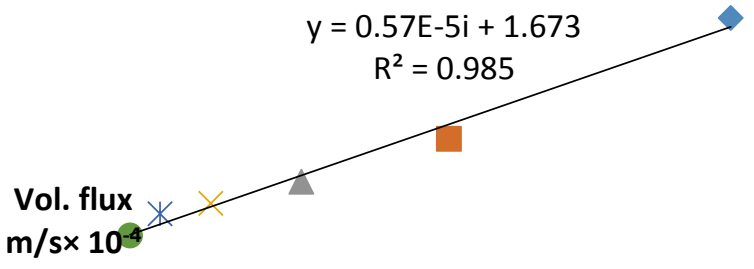

Hydraulic gradient

Fig. 2. Volume flux, $q$ against hydraulic gradient, $i$ (sample A)

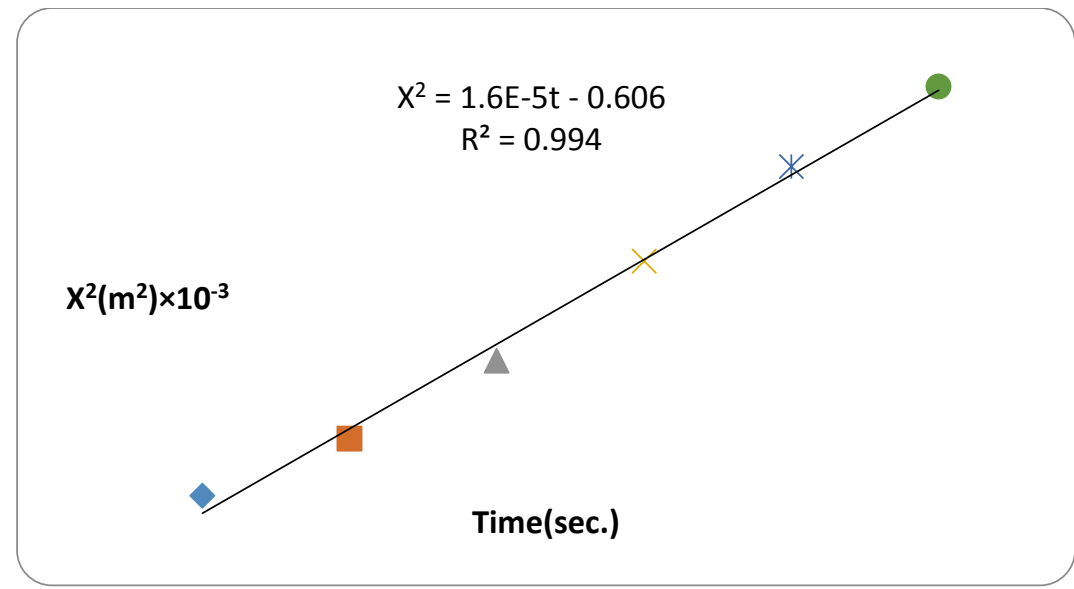

Fig. 3. Square of flow length $\left(x^{2}\right)$ against time $\mathrm{T}(\mathrm{Sec}$.$) for sample A$

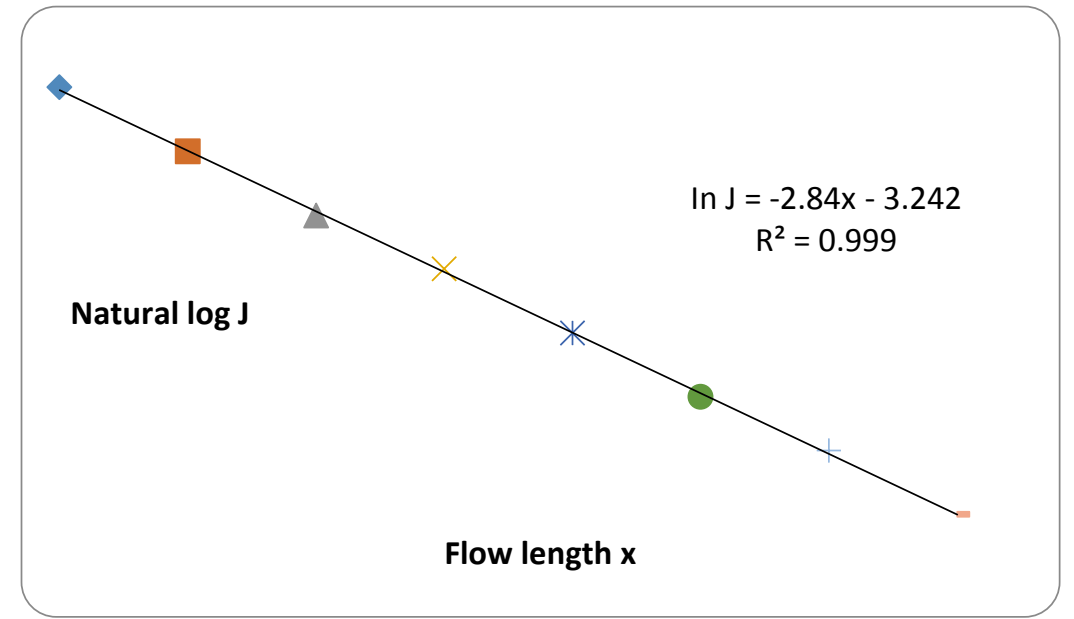

Fig. 4. Plot of natural logarithm of mass flux $\mathrm{J}$ against flow length $\mathrm{x}(\mathrm{m})$ for Sample A.

\section{CONCLUSION}

In this study, Darcy's and Fick's laws which govern the free flow of water and transport of contaminant in soils were used to develop a model which controls mass flux of contaminant in coastal aquifers. The medium with highest concentration coefficient of attenuation and the same time lowest concentration coefficient of diffusion will not allow saltwater contaminant to flow freely because of its low porosity and hydraulic conductivity. 
Therefore, maximum contact between saltwater contaminant and soil particles enhanced the attenuation capacity of the medium.

\section{REFERENCES}

[1] Bear, J., Cheng, A.H.-D., Sorek, S., Ouazar, D., Herrera, I., Seawater intrusion in coastal aquifers - concepts, methods and practices, Kluwer Academic, Publishers, Dordrecht, 1999.

[2] Schwart, F.W., Zhang, H., Fundamentals of groundwater, John Wiley \& Sons, Inc., New York, 2003.

[3] Barlow, P.M.,. Ground water in fresh water-salt water environments of the Atlantic Coast, U.S. Geological Survey Circular, 2003, https://pubs.usgs.gov/circ/2003/circ1262/.

[4] Cooper, H. H., Sea water in coastal aquifers, U.S. Geological Survey Water, Supply Paper, 1964.

[5] Delleur, J.W, The Handbook of groundwater engineering, CRC Press LLC, 1999.

[6] Domenico, P.A., Schwartz F.W., Physical and chemical hydrogeology, John Willey and Sons Inc., New York, 2000.

[7] Nag, P.K., Heat and mass transfer, published by Tata McGraw-Hill, Publishing Company Limited, 2008.

[8] Pekdeger, A., Matthess, G., Schroter, J., Protection of groundwater against pathogenic bacteria and viruses, hydrogeology in the servica of man, Memoires of the $18^{\text {th }}$ Congress of the International Association of Hydrogeologists, Cambridge, 1985.

[9] Floppen, J.W.A, van Herwerden, M., Schijven, J.F., Transport of escherichia coli in saturated porous media: dual mode deposition and intra-population heterogeneity, Water resources, vol. 41, no. 8, 2007, p. 1743-1753.

[10] Iwasaki, I., Some Notes on sand filtration, J. Amer.Water Works Assoc., vol 29,1937, p. 1591-1609.

[11] Ison, C.R., Ives, K.J., Removal mechanisms in deep bed filtration, Journal of Chemical Engineering Science, vol. 24 , no. 4 , 1969 , p. $717-729$. 